\title{
Próba modelowania prędkości przepływu wody oraz rozprzestrzeniania się zanieczyszczeń w jeziorze Gopło
}

\author{
Attempt modelling water velocity and the spread of contamination in the Gopło Lake
}

\section{Włodzimierz Juśkiewicz}

Katedra Geomorfologii i Paleogeografii Czwartorzędu, Uniwersytet Mikołaja Kopernika,Toruń,wwj@umk.pl

Zarys treści: W artykule omówiono modelowanie przepływu wody w jeziorze Gopło. Opisano zastosowane modele matematyczne, dane wejściowe oraz napotkane trudności. Przedstawiono użyte do modelowania siatki elementów skończonych oraz przykładowe symulacje rozprzestrzeniania się substancji w jeziorze. Dalszym etapem badań będzie korelacja źródeł zanieczyszczeń z zapisem w osadach dennych Gopła.

Słowa kluczowe: modele RMA, mapa prędkości, transport zanieczyszczeń, śledzenie cząstek, jezioro Gopło

\begin{abstract}
This paper discusses the modelling of the flow of water in the Gopło Lake. Describes the mathematical models used, the input data and the difficulties encountered. Presented used to model the finite element mesh and sample simulations spreading substances in the lake. The next stage of research will be the correlation of the sources of pollution in sediments record Gopło.
\end{abstract}

Key words: RMA models, velocity map, contaminant transport, particle tracking, Gopło Lake

\begin{abstract}
Wstęp
Badania osadów jeziornych i zakumulowanych w nich zanieczyszczeń stanowią pod wieloma względami istotną trudność dla osób zajmujących się stanem jakości jezior. Starają się one odpowiedzieć m.in. na pytanie: co, w jakiej ilości i skąd trafia do wód, a następnie osadów dennych zbiorników i jezior. O ile można odpowiedzieć na pytanie: co i w jakiej ilości zostało zakumulowane w osadzie, o tyle trudno jest określić położenie źródła zanieczyszczeń, sposób ich transportu i akumulacji. W odpowiedzi na tak postawione pytanie pomocne mogą być analizy numeryczne. Dzięki szybkiemu rozwojowi technik komputerowych modelowanie procesów zachodzących w środowisku staje się coraz bardziej możliwe i zbliżone do przebiegu zjawisk rzeczywistych.

$\mathrm{W}$ artykule przedstawiono wstępne wyniki symulacji rozprzestrzeniania się substancji w jeziorze Gopło. Do modelowania wykorzystano oprogramowanie Surface-water
\end{abstract}

Modeling System (SMS), które jest kompleksowym oprogramowaniem do jedno-, dwu- i trójwymiarowego modelowania hydrodynamicznego. Program rozwijany jest przez Environmental Modeling Research Laboratory (EMRL) w Brigham Young University we współpracy z U.S. Army Corps of Engineers Waterways Experiment Station (USACE-WES) oraz U.S. Federal Highway Administration (FHWA). SMS obsługuje różne modele, pozwalające obliczać m.in.: zmiany zwierciadła wody, prędkość wody przy stałych i dynamicznych warunkach przepływu, migrację zanieczyszczeń, zasolenie, transport osadu, falowanie.

W artykule zastosowano modele RMA2 i RMA4. RMA2 jest modelem dwuwymiarowym przepływu ważonego głębokością (Donnell 2004a). Model oblicza wysokość lustra wody i składowe poziome dla przepływu podkrytycznego zgodnie z równaniami opartymi na zasadach zachowania masy i pędu. Tarcie w tym modelu obliczane jest za pomocą formuł Manninga lub Chezy'ego, natomiast współczynniki lepkości są używane do określenia charak- 
terystyk turbulencji. RMA4 jest modelem uzupełniającym RMA2 i korzysta $\mathrm{z}$ danych wynikowych tego modelu, tj. prędkości i kierunku przepływu. RMA4 jest dwuwymiarowym numerycznym modelem obliczającym stężenie transportowanej substancji zanieczyszczającej wody (Donnell 2004b). Model ten zakłada jednolitą koncentrację zanieczyszczenia. Grupa modeli RMA pozwala śledzić procesy rozprzestrzeniania się substancji rozpuszczonych i nierozpuszczonych w wodzie, ukazuje procesy dyfuzji, adwekcji i rozpadu badanych substancji w czasie i przestrzeni.

\section{Charakterystyka hydrograficzna jeziora Gopło}

Jezioro Gopło znajduje się w rynnie polodowcowej, która powstała w wyniku subglacjalnej erozji wód lodowcowych (Molewski 1999). Rynna jest formą wyraźnie wydłużoną, o długości około 40 km, przy czym długość samego jeziora wynosi około $25 \mathrm{~km}$. Profil podłużny dna jeziora jest niewyrównany, występują w nim przegłębienia i progi utrudniające przepływ wody. Długość linii brzegowej jeziora wynosi około $91,3 \mathrm{~km}$, w tym około 4,0 km przypada na linię brzegową wysp, które łącznie zajmują powierzchnię 25,5 ha (ryc. 1). Tak długa linia brzegowa wynika także $\mathrm{z}$ obecności licznych zatok oraz rozdzielenia jeziora na dwie części: wschodnią, przepływową, oraz zachodnią, nieprzepływową. Podstawowe parametry jeziora wynoszą: powierzchnia zwierciadła wody około 2154,5 ha; rzędna zwierciadła wody od 76,8 do 77,2 m n.p.m. (do obliczeń przyjęto wysokość 76,82 m n.p.m.); średnia głębokość jeziora 3,6 m; głębokość maksymalna jeziora 16,6 m; przepływ w profilu Przewóz u wlotu Noteci do Gopła wynosi od 1,4 do $2,7 \mathrm{~m}^{3} \mathrm{~s}^{-1}$ (w obliczeniach dla uproszczenia przyjęto 3,0 $\mathrm{m}^{3} \mathrm{~s}^{-1}$ ); wskaźnik rozwinięcia linii brzegowej 5,55; objętość jeziora 78497 tys. $\mathrm{m}^{3}$.

Dopływy jeziora stanowią średnio 72 cieki, a ich liczba zmienia się w czasie w zależności od warunków hydrologicznych (ryc. 1). Głównym dopływem jest skanalizowana Noteć, która uchodzi do Gopła na jego południowym krańcu, a wypływa w jego północnej części. Do jeziora uchodzi również znaczna liczba kanałów. Ich rola w zasilaniu jeziora i doprowadzaniu zanieczyszczeń jest zmienna w czasie. Cała zlewnia bezpośrednia Gopła jest obszarem intensywnie wykorzystywanym rolniczo. Północne brzegi jeziora otacza obszar miejsko-przemysłowy Kruszwicy. Dodatkowo część kanałów odprowadza do Gopła wody wraz z zanieczyszczeniami z większych miejscowości, w tym: Radziejowa, Piotrkowa Kujawskiego i Dobrego. Oznacza to bardzo duże zróżnicowanie ilościowe i jakościowe zanieczyszczeń dostających się do jeziora.

\section{Podstawy i cel modelowania}

Podstawą do modelowania jest plan batymetryczny jeziora. Wykorzystany plan wykonany przez Instytut Ry-
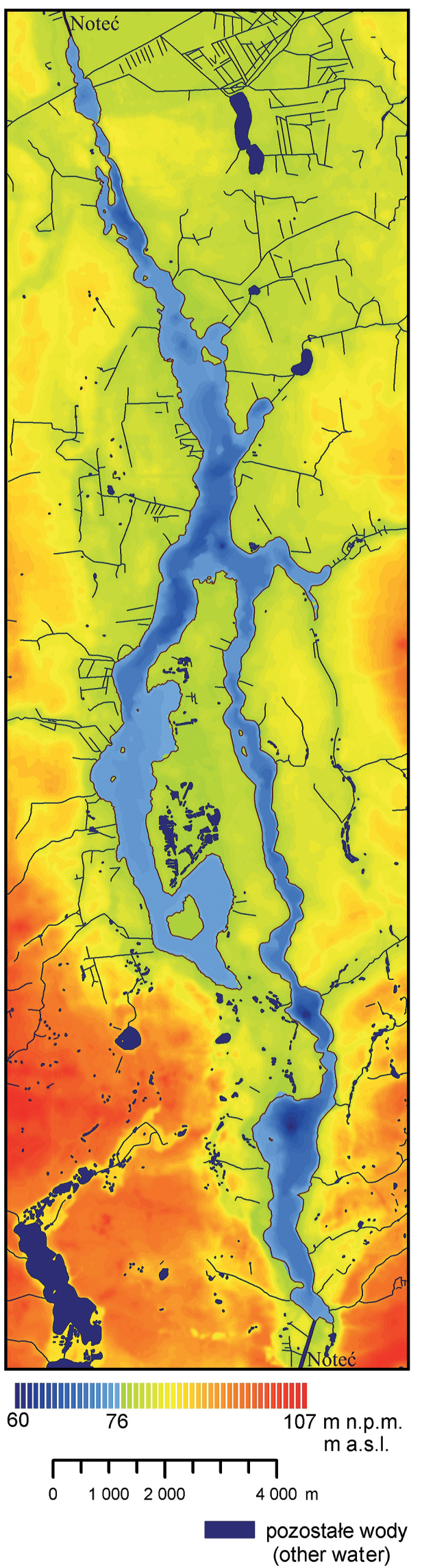

Ryc. 1. Cyfrowy model wysokościowy wraz z planem batymetrycznym jeziora Gopło

Fig. 1. Digital elevation model with a plan bathymetric Lake Gopło 


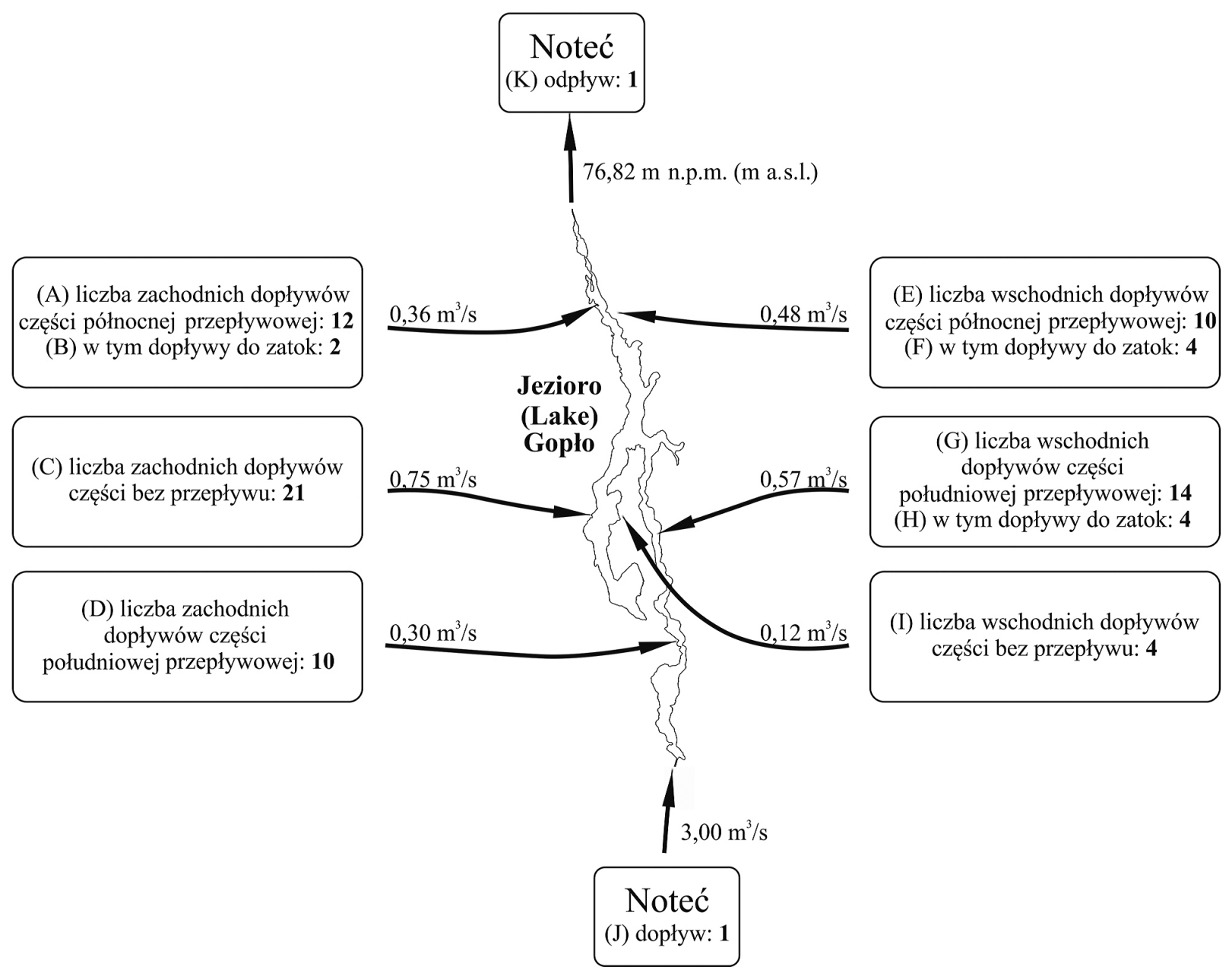

Ryc. 2. Schemat warunków brzegowych Gopła

Fig. 2. Schematic of boundary conditions of Gopło Lake

(A) number of western tributaries of the northern part of lake, with flow, (B) including tributaries to the bays, (C) number of western tributaries of the part of lake, without flow, (D) number of western tributaries of the southern part of lake, with flow, (E) number of the eastern tributaries of the northern part of lake, with flow, (F) including tributaries to the bays, $(\mathrm{G})$ number of the eastern tributaries of the southern part of lake, with flow, $(\mathrm{H})$ including tributaries to the bays, (I) number of the eastern tributaries of the part of lake, without flow, (J) main tributary, (K) main outflow

bactwa Śródlądowego w Olsztynie został zweryfikowany i unacześniony przez autora za pomocą echosondy dwuwiązkowej. Wyznaczono położenie wszystkich dopływów i odpływu z jeziora (ryc. 2). W przypadku dopływów określono wydatek dla poszczególnych cieków i kanałów $\mathrm{w} \mathrm{m}^{3} \mathrm{~s}^{-1}$, a dla Noteci, w miejscu jej wypływu z jeziora, wysokość zwierciadła wody w m n.p.m. Ustalono ilości zanieczyszczeń dostających się do jeziora z dopływów oraz dominujący kierunek i prędkość wiatru.

Aktualnym celem badań autora jest określenie rozprzestrzeniania się zanieczyszczeń pochodzących z dopływów jeziora w oparciu o modelowanie. Dalszym etapem badań będzie korelacja źródeł zanieczyszczeń $\mathrm{z}$ zapisem $w$ jego osadach dennych. Badania te, ze względu na ograniczoną ilość danych lub ich brak, będą miały przybliżony charakter. $\mathrm{W}$ przedstawionych przykładach modelowania część wymaganych parametrów pominięto lub zastały one uogólnione, jak również zastosowano symulacje chwilowe, a nie długookresowe.

\section{Równania matematyczne modeli}

W modelu RMA2 wychodzi się z założeń opartych na zasadach zachowania masy i pędu. Równania matematycz-

$$
\begin{aligned}
h \frac{\partial u}{\partial t} & +h u \frac{\partial u}{\partial x}+h v \frac{\partial u}{\partial y}-\frac{h}{\rho}\left(\mathrm{E}_{x x} \frac{\partial^{2} u}{\partial x^{2}}+\mathrm{E}_{x y} \frac{\partial^{2} u}{\partial y^{2}}\right) \\
& +g h\left(\frac{\partial a}{\partial x}+\frac{\partial h}{\partial x}\right)+\frac{g u n^{2}}{\left(h^{1 / 6}\right)^{2}}+\left(u^{2}+v^{2}\right)^{1 / 2} \\
& -\zeta V_{a}^{2} \sin \psi+2 h \omega v \sin \phi=0 \\
h \frac{\partial v}{\partial t}+ & +h u \frac{\partial v}{\partial x}+h v \frac{\partial v}{\partial y}-\frac{h}{\rho}\left(\mathrm{E}_{y x} \frac{\partial^{2} v}{\partial x^{2}}+\mathrm{E}_{y y} \frac{\partial^{2} v}{\partial y^{2}}\right) \\
& +g h\left(\frac{\partial a}{\partial y}+\frac{\partial h}{\partial y}\right)+\frac{g n^{2}}{\left(h^{1 / 6}\right)^{2}}+\left(u^{2}+v^{2}\right)^{1 / 2} \\
& -\zeta V{ }_{a}^{2} \sin \psi+2 h \omega v \sin \phi=0 \\
& \frac{\partial h}{\partial t}+h\left(\frac{\partial u}{\partial x}+\frac{\partial v}{\partial y}\right)+u \frac{\partial h}{\partial x}+v \frac{\partial h}{\partial y}=0
\end{aligned}
$$


ne modelu mają postać (1):

gdzie:

$h$ - głębokość wody,

$u, v$ - prędkości w kierunkach kartezjańskich,

$x, y, t$ - koordynaty kartezjańskie i czas,

$\rho-$ gęstość wody,

E - turbulentny wskaźnik lepkości; dla xx - normalny kierunek na osi x powierzchni, dla yy - normalny kierunek na osi y powierzchni, dla xy i yx - kierunek ścinania na każdej powierzchni,

$g$ - przyspieszenie ziemskie,

$a$ - rzędna dna,

$n$ - współczynnik szorstkości Maninga,

$\zeta$ - empiryczny współczynnik ścinania wiatru,

$V_{a}$ - prędkość wiatru,

$\Psi$ - kierunek wiatru,

$\omega$ - parametr Coriolisa,

$\Phi$ - lokalna szerokość geograficzna.
Dla uproszczenia ze względu na istotne dysproporcje między długością i szerokością jeziora a jego głębokością model można zredukować do dwóch wymiarów, pomijając ruch wody w pionie (Hachaj 2007). Gęstość wody przyjęto za wartość stałą.

Model RMA4 opisuje procesy transportu i mieszania się unoszonych zanieczyszczeń. W tym wypadku równanie przybiera postać (2):

$$
h\left(\frac{\partial c}{\partial t}+u \frac{\partial c}{\partial x}+v \frac{\partial c}{\partial y}-\frac{\partial}{\partial x} D_{x} \frac{\partial c}{\partial x}-\frac{\partial}{\partial y} D_{y} \frac{\partial c}{\partial y}-\sigma+k c+\frac{R(c)}{h}\right)=0
$$

gdzie:

$h$ - głębokość wody,

$c$ - stężenie zanieczyszczenia dla danego składnika,

$\mathrm{t}$ - czas,

$u, v$ - prędkości w kierunkach kartezjańskich,

$D_{x}, D_{y}$ - współczynnik mieszania turbulentnego (dyspersja)

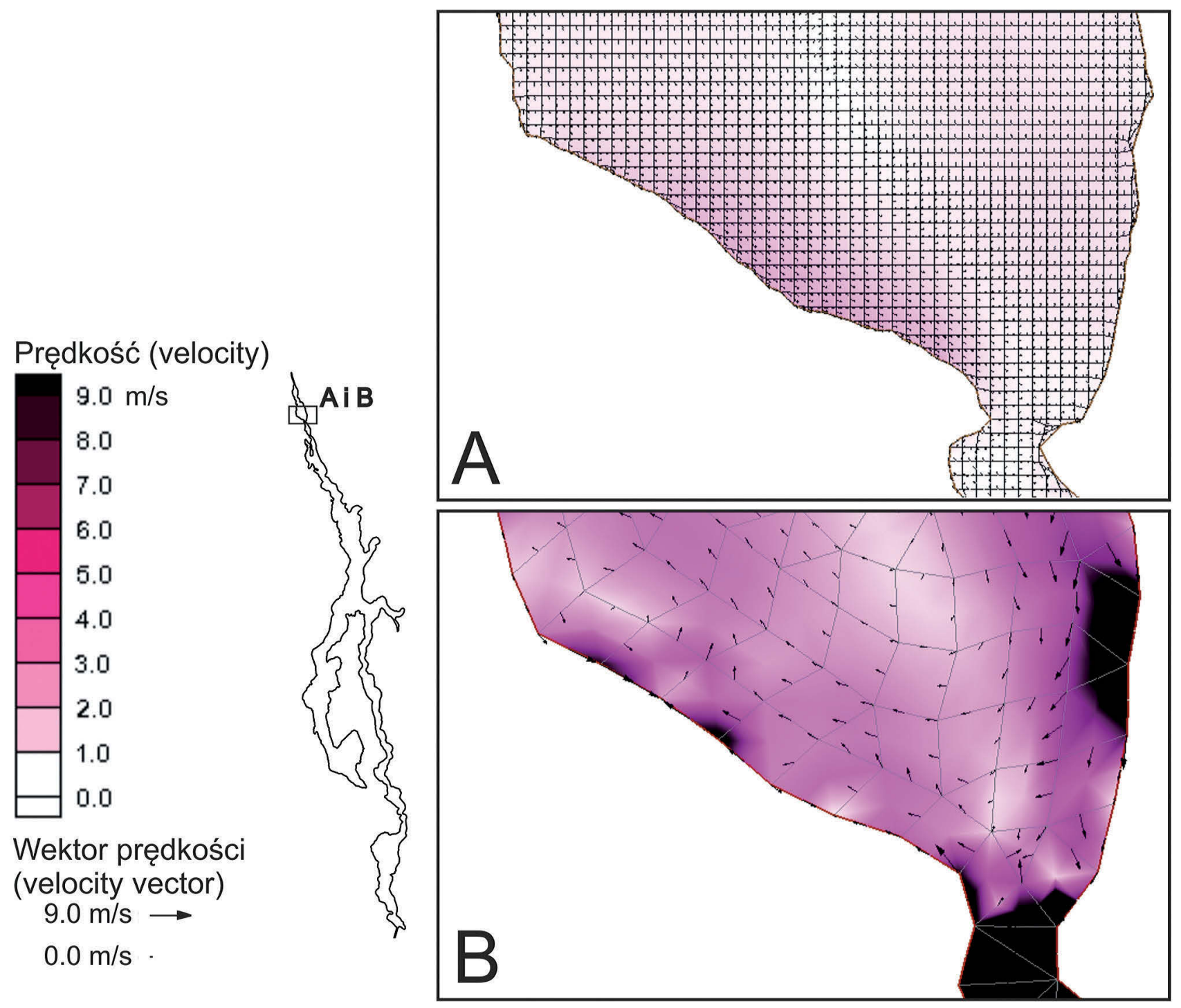

Ryc. 3. Mapy pola prędkości dla wybranego obszaru jeziora Gopło

A - półautomatyczna siatka o rozdzielczości $10 \mathrm{~m}, \mathrm{~B}$ - automatyczna siatka o rozdzielczości około $50 \mathrm{~m}$

Fig. 3. Maps of the velocity field for the selected area of Gopło Lake

A - semi-automatic mesh with a resolution of $10 \mathrm{~m}, \mathrm{~B}$ - automatic grid with a resolution of about $50 \mathrm{~m}$ 


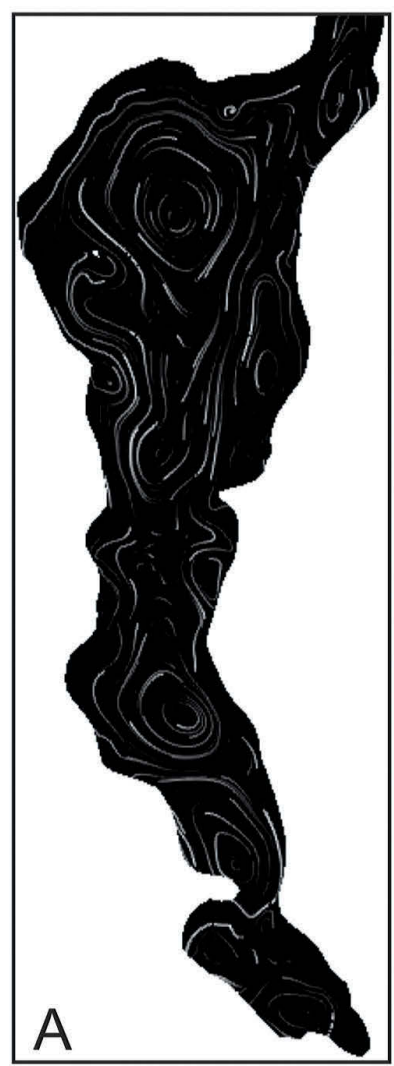

$11 \mathrm{~m} / \mathrm{s}(\mathrm{W})$

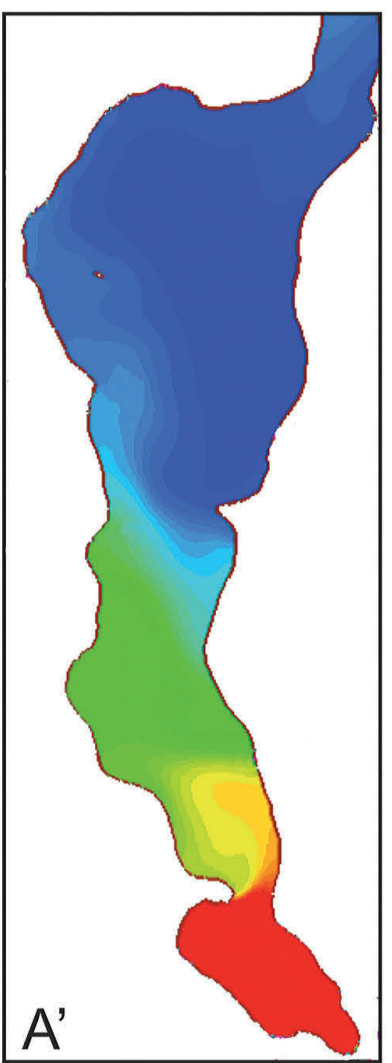

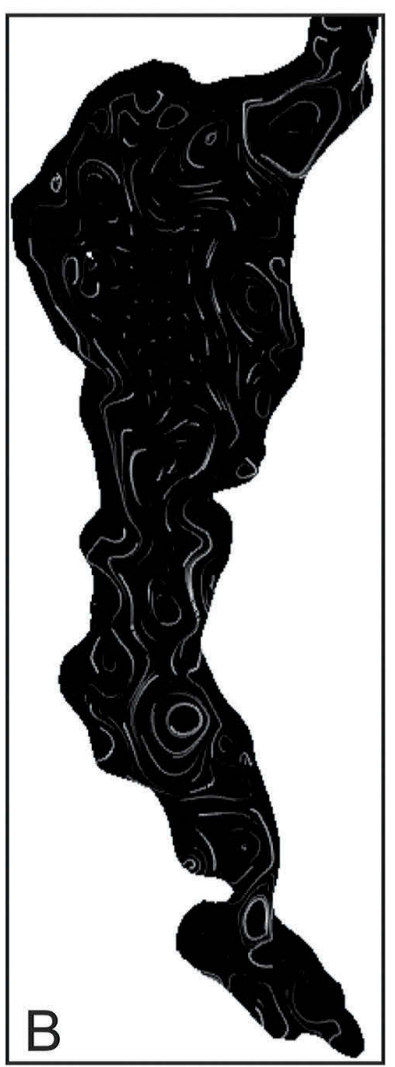

$0 \mathrm{~m} / \mathrm{s}(-)$

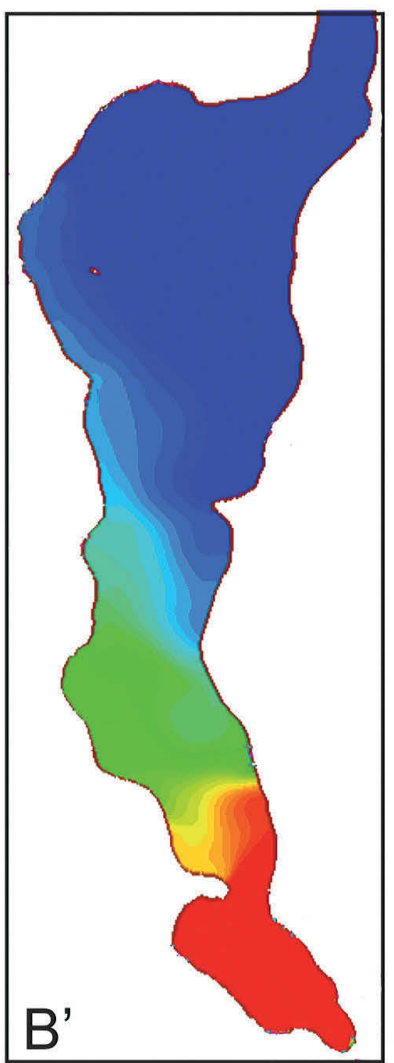

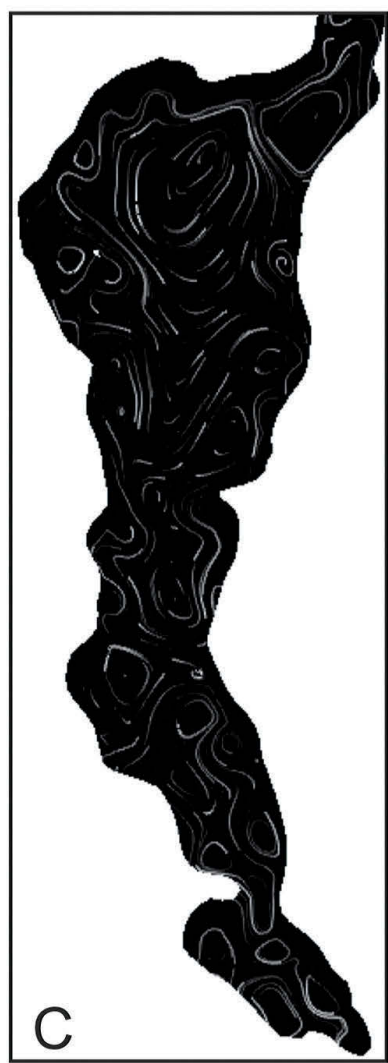

$11 \mathrm{~m} / \mathrm{s}(\mathrm{E})$

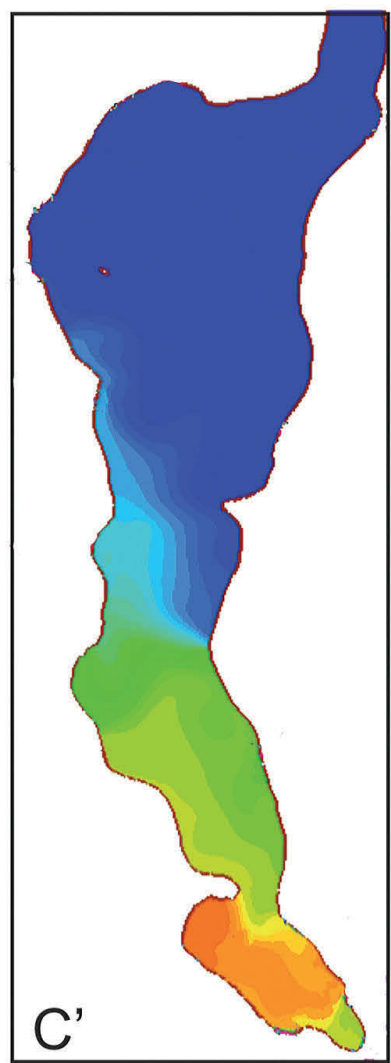

Ryc. 4. Wpływ wiatru na tory cząstek i rozprzestrzenianie się zanieczyszczeń

A, A' - wiatr zachodni, $11 \mathrm{~m} \mathrm{~s}^{-1}, \mathrm{~B}, \mathrm{~B}^{\prime}$ - brak wiatru, C, C' - wiatr wschodni, $11 \mathrm{~m} \mathrm{~s}^{-1}$

Fig. 4. The influence of wind on the tracks of the particles and the spread of contamination $\mathrm{A}, \mathrm{A}^{\prime}$ - west wind, $11 \mathrm{~m} \mathrm{~s}^{-1}, \mathrm{~B}, \mathrm{~B}^{\prime}-$ no wind, $\mathrm{C}, \mathrm{C}^{\prime}$ - east wind, $11 \mathrm{~m} \mathrm{~s}^{-1}$ 
$k$ - kolejność zaniku zanieczyszczenia, $\sigma$-źródło składnika,

$R(c)$ - wskaźnik opadów/parowania.

W modelowaniu pominięto wpływ opadów i parowania ze względu na symulacje chwilowe. Równania modeli RMA2 i RMA4 rozwiązano metodą elementów skończonych, stosując residua ważone Galerkina.
W przypadku modelu hydrodynamicznego RMA2 oraz w modelu transportu RMA4 obliczeń dokonano na siatce dwuwymiarowych czworoboków lub trójkątów (np. przy linii brzegowej jeziora lub strefach przewężeń), których liczba w przypadku czworoboków była maksymalna w danym modelu.
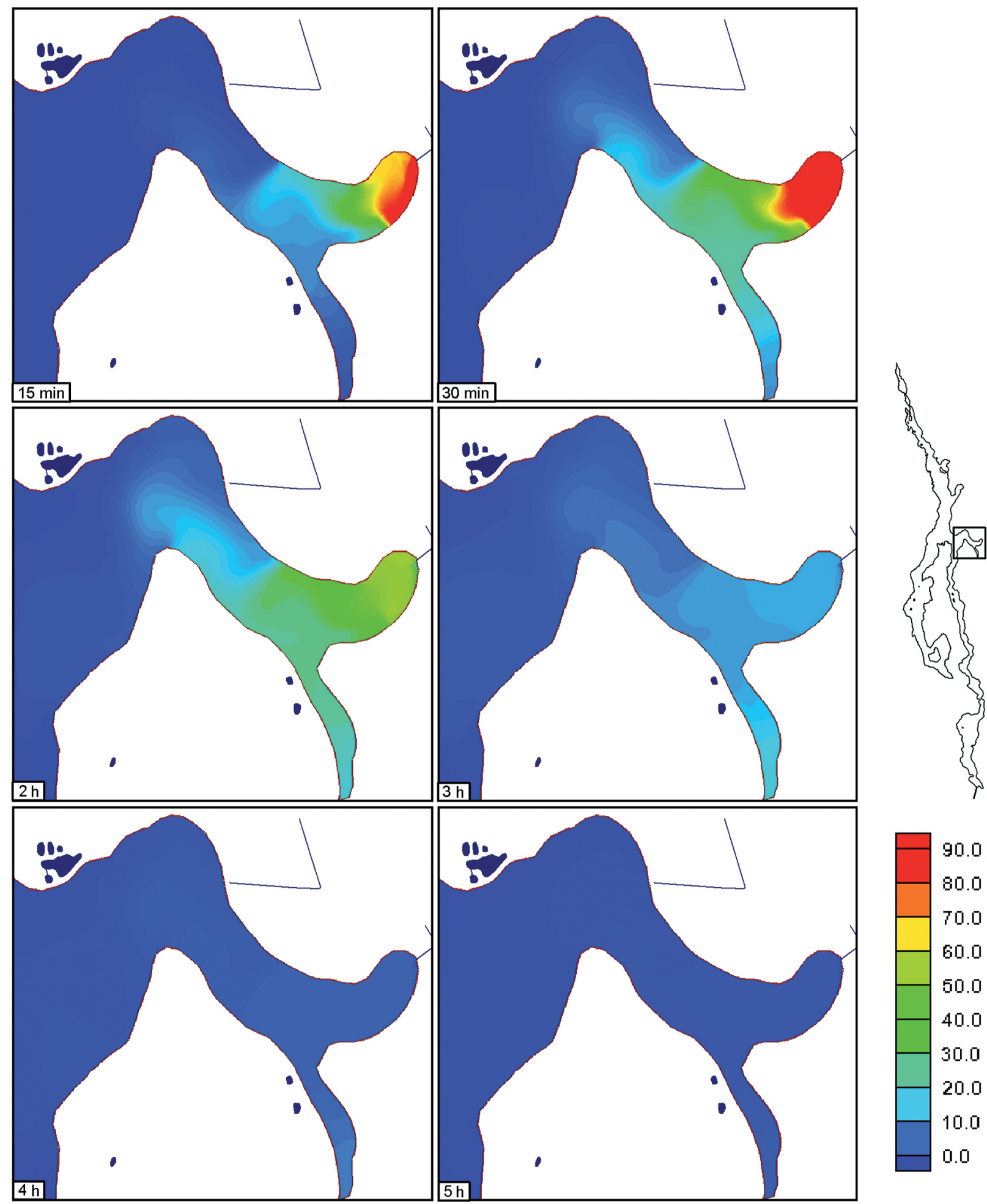

$90.0 \mathrm{mg} / \mathrm{l}$

80.0

70.0

60.0

50.0

40.0

30.0

20.0

10.0

0.0

Ryc. 5. Przykład modelowania rozprzestrzeniania się zanieczyszczeń w wodach Gopła

Fig. 5. Example modeling of the spread of contamination in the Gopło Lake waters 


\section{Problem konstruowania siatki elementów skończonych}

Siatkę elementów skończonych utworzono w module Mesh programu SMS. Powstał szereg siatek o różnej rozdzielczości. Dwie skrajne z przyjętych gęstości siatek generują automatycznie różne prędkości wody w jeziorze (ryc. 3). Model A został oparty na wykonanej przez autora szczegółowej siatce 600000 punktów i rozdzielczości oczka siatki $10 \times 10$ $\mathrm{m}$ (ryc. 3A). Zastosowanie tak gęstej siatki wymaga podzielenia obszaru jeziora na pięć części, co wynika z możliwości obliczeniowych programu, bowiem maksymalna liczba węzłów siatki ograniczona jest do 300 000. Komplikuje to modelowanie na kontakcie poszczególnych części jeziora. Wariant B to siatka generowana głównie automatycznie (ryc. 3B). Jej rozdzielczość została zmniejszona do oczka siatki średnio $50 \times 50 \mathrm{~m}$, przy liczbie węzłów siatki około 32000 . Przyspieszyło to prędkość obliczeń, jednak pojawiły się wyraźnie zawyżone prędkości wody. Powstają one w strefie litoralnej jeziora $\mathrm{w}$ miejscach ujściowych dopływów i dochodzą do kilku metrów na sekundę (ryc. 3B). Model A w efekcie większego zagęszczenia siatki uzyskuje prędkości wody zbliżone do oczekiwanych (rzeczywistych). Średnie prędkości wody wahają się między $0,0-0,4 \mathrm{~m} \mathrm{~s}^{-1}$ (ryc. 3A).

Istotne różnice $\mathrm{w}$ szacowanej przez obydwa modele prędkości wody wskazują na konieczność indywidualnego dopasowania do każdego akwenu siatki obliczeniowej przez wykonanie szeregu prób. Zdaniem autora procedurę należy rozpocząć od automatycznego wygenerowania siatki elementów skończonych, a następnie zagęszczać ją w miejscach, gdzie wyniki modelowania wyraźnie odbiegają od oczekiwanych, np. gdy prędkość wody w jeziorze w miejscu ujścia cieku wyraźnie przekracza jego przepływy. Ponadto w siatce powinny dominować czworoboki nad trójkątami, a ich kąty wewnętrzne powinny być zbliżone do $90^{\circ}$. Najlepszym rozwiązaniem jest kalibracja modelu w oparciu o pomiary rzeczywiste w terenie, zazwyczaj trudne do pozyskania, które pozwoliłyby na jego walidację i uszczegółowienie.

\section{Przykłady modelowania}

Przeprowadzone modelowanie prędkości i kierunku ruchu wody w Gople (model RMA2) jest punktem wyjścia dla modelowania rozprzestrzeniania się zanieczyszczeń w jeziorze (model RMA4). Ciekom przypisuje się określony ładunek zanieczyszczeń $\mathrm{w} \mathrm{mg} \mathrm{dm}^{-3}$ oraz czas ich rozprzestrzeniania, np. w godzinach. Na modelu można prześledzić ruch cząstek określonej substancji.

$\mathrm{Na}$ rycinie 4 przedstawiono różnice w mapach torów cząstek oraz rozprzestrzeniania się zanieczyszczeń doprowadzanych przez Noteć o przepływie $3,0 \mathrm{~m}^{3} \mathrm{~s}^{-1}$. Przyjęto stały ładunek zanieczyszczeń $1000 \mathrm{mg} \mathrm{dm}^{-3}$ doprowadzany przez jedną godzinę do skrajnie południowej części jeziora, przy zmianie tylko jednego parametru, tj. prędkości wiatru. Symulacja prezentuje jedynie trzy sytuacje: przy przyjętej takiej samej prędkości dla wiatru zachodniego i wschodniego oraz przy braku wiatru.
W kolejnym przykładzie przedstawiono możliwości określenia zasięgu rozprzestrzeniania się zanieczyszczeń doprowadzanych przez ciek o przepływie $0,06 \mathrm{~m}^{3} \mathrm{~s}^{-1}$ (ryc. 5). Wpływ wiatru został pominięty. Dla cieku uchodzącego do zatokowej części jeziora przyjęto analogiczny, stały ładunek zanieczyszczeń, tj. $1000 \mathrm{mg} \mathrm{dm}^{-3}$, doprowadzany przez jedną godzinę. Potem następował czas obserwacji rozprzestrzeniania się i całkowitego rozproszenia substancji w akwenie. Z modelu wynika, że rozprzestrzenianie się substancji jest ograniczone do części zatokowej jeziora i zanika po 5 godzinach.

\section{Podsumowanie i wnioski}

Pomimo że zastosowane modelowanie nie uwzględnia szeregu uwarunkowań, zdaniem autora może stanowić podstawę do szacowania rozprzestrzeniania się zanieczyszczeń w krótkim czasie. Modelowanie tego typu procesów w długim okresie wymaga określenia szeregu zmiennych, najczęściej niemożliwych do pozyskania.

Należy podkreślić, że kluczowe znaczenie dla poprawności rezultatów modelowania ma staranność wykonania siatki elementów skończonych, w tym możliwość jej kalibracji w oparciu o badania terenowe.

W dalszym etapie badań modelowanie długookresowe może stanowić podstawę do określenia koncentracji zanieczyszczeń w osadach i powiązania jej z miejscami ich zrzutu. Potencjalnie może to ułatwić ustalenie związków między składem geochemicznym osadów a zinwentaryzowanymi w przestrzeni i czasie źródłami substancji zanieczyszczających. Poprawnie wykonany model może stanowić również podstawę do prognozowania, ochrony i monitoringu osadów dennych.

\section{Podziękowanie}

Pracę zrealizowano w ramach grantu MNiSW „Geochemiczne i sedymentologiczne zróżnicowanie osadów jeziora Gopło na tle modelowania komputerowego i metod geostatystycznych wspierających rozpoznanie i interpretację zmienności cech ilościowych i jakościowych osadu w czasie i przestrzeni” nr N306 722640.

\section{Literatura}

Donnell B.P., 2004a. User Guide to WES-RMA2 Version 4.5. Waterways Experiment Station, Costal and Hydraulics Laboratory, California, Davis.

Donnell B.P., 2004b. User Guide to WES-RMA4 Version 4.5. Waterways Experiment Station, Costal and Hydraulics Laboratory, California, Davis.

Hachaj P.S., 2007. Modelowanie pola prędkości wody w Zbiorniku Dobczyckim - budowa siatki obliczeniowej i wstępne wyniki. Czasopismo Techniczne 15, Środowisko 2-Ś. Wyd. Politechniki Krakowskiej, Kraków.

Molewski P., 1999. Rynna Gopła - problem jej genezy i roli w odpływie wód roztopowych podczas zlodowacenia vistuliańskiego. Stud. Soc. Sci. Torun. 10 (6). 